\title{
FISHERMAN'S WORK AND THE SEA IN THE LIVONIAN FOLK CALENDAR
}

\section{$\underline{\text { Kristi Salve }}$}

Various approaches are known to have been used to study folk calendars and to publish the material. The most frequently used (and probably the most natural)

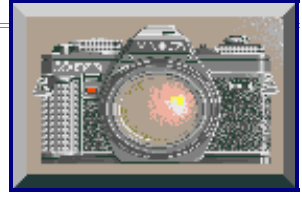
of them is to take a holiday or festival and make a survey of all pertinent beliefs and customs. But it is also possible to focus on a certain belief and/or custom or on a major ritual complex that may associate with several holidays or festivals celebrated in a community.

The Livonian folk calendar has been patient of both methods. Special studies have been published on the Livonian traditions of Shrovetide and St. Nicholas' Day (Loorits 1958; Salve 1984). O. Loorits was planning to survey the whole year's holidays and festivals in Vol. IV of his Livonian Folk Religion, but unfortunately he could not finish the manuscript. He did publish, however, a shorter version of the study, in which we find not only the names and explanations of the meaning of the annual holidays and festivals, but also a survey of the Livonian traditional views on the category of time and their chronology together with the respective terms, as well as of their beliefs connected with lunar phases and the days of the week (Loorits 1950).

The present article, however, addresses very different beliefs and customs that belong to different holidays and festivals, but are connected by a common function: they all were once meant to predict or guarantee success in fishing by such means as are dictated by a magic-oriented way of thinking. This survey is based on all relevant material available in print, on phonographs and in manuscripts. Those sources have mostly been listed in my previously published articles on the Livonian folk calendar (Salve 1984; 1987). The only new source was the manuscript by O. Loorits which was kept in the author's possession and thus was not available for use in Estonia until quite recently.

In an earlier publication of mine I have referred to O. Loorits who argues that the Livonian folk calendar is one of land cultivators and cattle-breeders, thus reflecting little of fishermen's work (Loorits 1950, 108). Hitherto there has hardly been any reason to dispute this statement. On the contrary, it seems to have found increasing confirmation. It looks eloquent indeed that for the Livonians even the Day of St. Nicholas, who was, after all, the patron saint of sailors, had no association with the sea whatsoever, being celebrated as a horses' holiday instead. Also, in a fishermen's calendar one would perhaps expect to find some more emphasis laid on St. Peter's Day as Apostle Peter was a fisherman too. Mumming was practised by the Livonians mostly for entertainment. The accompanying functions of productivity magic were predominantly connected with cattle-breeding, while the main emphasis was laid on sheep (Salve 1984, 105, also 101, 111). The clothing of the mummers, however, seems indicative of flax-oriented magic (Salve 1984, 110). The reasons for the above situation seem to lie, on the one hand, in the fact that agriculture, and especially cattle-breeding occupied a rather important place among the Livonian people's sources of living. On the other hand we should not underestimate the possible influence of some other peoples' traditions. 
And yet here is no doubt that during the period and in the territory whence comes our information on the Livonian folk calendar (i.e. in twelve villages on the coast of Kurland since the middle of the 18th century) the main livelihood was maritime fishing. F.J. Wiedemann, who actually laid the foundations to Livonian ethnology, wrote metaphorically that as the Livonian soil was poor their true field was the sea and nets were their plough. Fish, especially Baltic herring and sole (cooked or fried fresh, salted, dried or smoked) was not only their main food, but also an important merchandise (Sjögren - Wiedemann, LXXII). Eloquent in this sense is also the self-designation of the Kurland Livonians who call themselves kalamied 'fishermen'. The other popular name randalist 'coast-dwellers', also used by the Latvians as a loan translation, refers to a close connection with the sea as well (Sjögren - Wiedemann, XI-XII). V. Wallin-Voionmaa, who represents the next generation, has also pointed out that the Livonians consider the sea as their own land and claim to have been born in a boat. Agricultural work was not so highly valued (Alho 1891, 22-25). The same was true about the 1920 s when F. Linnus stated that the Livonians' main living was earned by fishing and sea-faring (Leinbock 1928, 109).

So, although there is good reason to agree with O. Loorits in that the position of the sea in the Livonian folk calendar was not equal to its role in the people's life, a more thoroughgoing approach reveals quite an interesting variety of relevant material.

The following discussion proceeds from festival to festival, starting from the beginning of the year and finishing with New Year as it is so closely connected with Christmas. Of winter dates our interest should focus, first and foremost, on St. Anthony's Day (January 17). Being the patron saint of domestic animals and especially of hogs in many places throughout Europe, he came to be worshipped almost as a God of Hogs in south-eastern Estonia and a large territory in Latvia. St. Anthony was offered sacrifices and addressed with incantations in order to make hogs thrive (Lätt 1971).

The Livonian tradition also associates St. Anthony's Day with hogs. Their thriving was endeavoured by cooking and eating a hog's head, by taking the bones to the forest and by observing various bans. It was prohibited, for example, to comb one's hair on that day as such behaviour was said to bring lice onto the hogs' backs. (photo *1) Various sanctions were to befall those who dared work with wool or linen on that day. Like the Estonians and Latvians, the Livonians were also afraid that if the ban was broken, their hogs would be afflicted with some disease. In Livonia, however, much more attention was paid to a more complicated belief that those who broke the ban on certain works on St. Anthony's day would be punished by the hogs. Pigs could, for example, eat up the lambs of the person working with wool on that day. For fishermen a particularly important ban was concerned with netmaking. Whoever happened to do anything with his fishing nets that day, or spin thread for nets, or otherwise deal with linen had to consider the possibility that in summer his hogs would rip up his nets left on the seashore to dry. Note that this belief as well as the rest of the calendar traditions connected with hogs reflect the fact that the animals were allowed to run free. Often the Livonians would build fences to protect their fields, so that the animals could feel free to find their own food anywhere else. Of course a loose pig could suddenly find itself nuzzling at a fishing net left to dry. As net-mending was a big extra job people naturally tried to prevent it in every possible way.

To the background of the general scarcity of information available on the Livonian folk calendar, the ban on netmaking (or any preparatory activities for it) stands out strong indeed coming up in as many as seven reports from different villages. The single report to the effect that one should not go 
out to sea on St. Anthony's Day looks a bit shaky, all the more that the weather would hardly be right for maritime fishing at that time anyway. Maybe that report was just an improvisation to underline the importance of the holiday. (photo*2)

Notably, although the sanction for breaking the netmaking ban on St. Anthony's Day is firmly established with the Livonian people, the Latvian tradition does not have it in this form. In Latvia St. Anthony's was the hogs' holiday all right, but handicraft was forbidden that day just in order to prevent the pigs from falling ill. Neither have we found any association between St. Anthony's Day and the sea or fishing in Latvia, not even in the comprehensive publication by P. Smits whose ambition was to provide a truly exhaustive survey of all beliefs. On the western Estonian coast and the islands, however, the breaking of the netmaking ban on St. Anthony's Day was known to bring the same sanction as with the Livonians, namely the pigs would rip the nets up (Lätt 1970, 33, 40).

The next date to be mentioned in this connection is Candlemas (February 2). True, the single report connecting it with fishing need not prove much. Even though the paucity of material on the Livonian calendar tradition raises the informative potential of reports so that even a single report may refer to a well-rooted belief or custom, in this case doubts are raised by the form of the report. Notably, here we do not have the usual if - then pattern. The informant seems rather to have been mediating an interesting experience of his: a relative living near Ventspils (the Livonian Vänta) had once foretold a good autumn catch of Baltic herring, doing it from the amount of rime and snowfall on Candlemas Day. According to the informant the prediction came true. Wih some reservation it could be mentioned that according to Christian calendar Candlemas was sometimes considered as the end of the Christmas season. As follows from the text below, it was customary to predict the next season's catch from the weather of Christmas. As we know, the turn of the year is favoured as the right time for prophesying in general. As to the report in question it also leaves open the ethnicity of the informant's relative: he may either have been a Livonian who had moved away from his seaside home, or a Latvian relative by marriage. On the one hand, in Latvia Candlemas weather has really been considered augural for the weather in summer, the bounty of the year or the harvest of some concrete crop, but there is nothing on fishing (Smits IV, $1785 \mathrm{ff}$.). On the other hand the Estonian material seems to support the possibility that the occasional Livonian text may still be indicative of a tradition. Notably, there are some reports from Saaremaa that Candlemas snowfall was believed to bring a good catch (Lätt 1970, 78, 84). By the way, the fishermen from Lake Peipsi had quite a different belief connected with the day: as Candlemas was an important church holiday it was considered sinful to go fishing on that day (Lätt 1970, 68, 81).

In the Livonian folk tradition an established association seems to exist between fishermen's work and Shrove Tuesday. Although Shrove Tuesday is a movable feast that can happen quite early in February when winter is still in full force, it has been regarded as a herald of the approaching spring. For fishermen it meant that the fishing season was drawing near and one had to start thinking of preparations. As to the principal meanings of Shrove Tuesday it was, on the one hand, a women's feast (women and especially girls were the leading figures in mumming and the following village dance - v. Salve 1984, 108-111), but on the other hand it was clearly a fishermen's feast. By that time the winter's job of netmaking had to be finished, which rule found a figurative expression in the saying that the netmaking fork was to have been taken out of the house by Shrove Tuesday. Those who had not finished this work could get the fork tied on their back by mummers. The end of inside work was also marked by the instruction that the finished nets for off-shore fishing should be spread out.(photo *3) 
What made the occasion a real fishermen's feast, however, was not so much connected with the above-mentioned netmaking business, but with fishermen getting together on that day in order to find partners and conclude agreements for the next season. Some would renew old agreements, some would make new ones. The men were sitting at table, eating beans and wetting the deal. The report that incantations were sung to invite fat sole to come to 'our' waters and to persuade lean sole to leave for other seas, looks like an occasional transfer. Normally the motif is an obligatory component of a song sung on Easter morning (v. below).

Among the Estonian fishermen joint feasting on Shrove Tuesday was not practised, but it was customary with the Latvian fishermen dwelling on the coast of the Livonian Bay (Loorits 1985, 129-130). Here we probably have a merger of the Livonian and Latvian traditions. This applies to Shrovetide customs in general. Of all Livonian mummers, for example, those seen at Shrovetide looked the most similar to their Latvian colleagues. The couple of Estonian reports on Shrovetide being in any way connected with fishing are of a totally different nature. At Sõrve (Saaremaa) an incantation was sung to bring good luck in fishing. In Muhu netmaking was a must immediately before taking the sleigh and having the fun of a Shrovetide ride (Lätt 1970, 108, 116). As the reader will have noticed the public festivity of the Livonian and Latvian Shrovetide traditions is not characteristic of the Estonians. Instead some quiet magic was practised, but it deserves mentioning that the reports come from an area that was in close contact with the Livonian people. (photo*4)

Ash Wednesday, that follows Shrove Tuesday also had a prominent place in the Livonian folk calendar. This is connected with the largely entertaining function of masked 'belly-cutters' as well as with various bans and obligations. Although most of the bans concern housework, there is one report of an obligation to work at fishing nets on that day. This seems to run counter to the more traditional demand that netmaking be finished by Shrove Tuesday. There is, however, a slight possibility that the rather vague expression 'working at fishing nets' actually meant some ritual procedure performed to bring good fishing luck. Somehow the success of the forthcoming season also seems to have been associated with the ritual transition to seafood on that day. As the saying goes: Ash Wednesday opens the turbot cask. One of the major reasons underlying this transition was, of course, the beginning of fasting according to the catholic church calendar. And meat had usually been finished by that time anyway.

Beside many other examples the relative independence of calendar traditions and real life is illustrated by the fact that although Shrove Tuesday could happen in the depth of winter, it has a definite orientation towards spring, whereas some other popular dates that are not movable at all and are usually characterised by the appearance of some obvious signs of spring, are totally irrelevant to our subject. There are, for example, no reports of St. Matthew's Day having any bearing to fishing. But this can also be due to the general paucity of calendar material collected from the Livonian territory. The Estonian material, especially that coming from the islands and the western Estonian coast, contains some reports according to which it was prohibited to make nets on that day, and some others that, on the contrary, argue for doing it, just in order to ensure good luck in fishing (Lätt 1970, 167, 175-176). In the Latvian tradition St. Matthew's Day seems to be of little importance too, no connection with fishing has been reported.

As to Lady Day (March 25) there is a Livonian proverb saying that this is the day when seal cubs have their first swim (LV 486). A similar report has been received from Hiiumaa (EV 12297). Beliefs and magic rites practised on this day in connection with fishing are mostly found around 
Lake Peipsi and other inland waters. The Livonian Bay, however, is almost virginal in this respect. (photo *5)

Easter is another movable feast strongly connected with the sea and fishing. This is no wonder at all considering its falling on the period from end of March to end of April, old style. First let us discuss Maundy Thursday and Good Friday, that are inseparable from Easter and are known for various rituals performed. The Livonian fishermen, for example, used to smoke their nets over an anthill in the morning of Maundy Thursday, trying to do it in secret. Similar magic was practised by the Estonian fishermen who used to make, mend and smoke their fishing nets on that day. This was mostly practised on the western coast and on the islands, but not only there (Hiiemäe 1981, 177178). As to the Latvians they are also known to have believed that the nets made on Maundy Thursday, especially at church time, would bring a fine catch (Smits IV, 2036).

Good Friday attracts more attention in the Livonian calendar. The future catch was believed to increase if some firewood and chips were brought in before sunrise that morning. A formal analogy was even assumed to exist between the wood brought in and the fish expected to be caught: broad and thin chips were thought to attract flat sole, whereas thick logs symbolised big and fat fish. In Estonia a similar custom is not known to have had this meaning. The ritual practised on Good Friday in order to guarantee good fishing luck and safety at sea was similar to that performed both by the Estonians and the Livonians on the previous day (Hiiemäe 1981, 215). The Estonian custom of 'fetching birdwood' had quite a different purpose of ensuring success in bird's-nesting in the forthcoming summer. There is just one report of fishing luck to have been sought by bringing wood in, and this was noted down in South-East Estonia (Hiiemäe 1981, 224). The Latvian magic for Good Friday was the same as practised on Maundy Thursday, i.e. it was considered useful to make nets and immerse them (Smits II, 1051). Both days being internationally known as favourable for various acts of magic, the Livonian way of trying to ensure good fishing luck by bringing in wood looks rather original, at least among the surrounding customs and traditions.

As appears from the above discussion, the acts of magic of Maundy Thursday and Good Friday were mostly performed at home, quietly and sometimes even in secret. Easter Sunday, however, turns over a new leaf with its public and festive character. As has repeatedly been emphasized by $\mathrm{O}$. Loorits, Easter occupied a central place in the earlier Livonian tradition. This is also confirmed by the originality and survival of some special songs until relatively recently (Loorits 1936, XIV). Beside the Birds' Awakening song analysed in more detail below, the Livonian repertoire contains as an exception - a sacred song that is said to have been sung at church first (Loorits 1936, 570571). There is still another important song in which one is reminded of Christ's resurrection, but that has an obvious connection with the incantation-like Birds' Awakening (Loorits 1936, 571). Most of the known variants of the last mentioned song have been published by Loorits (1936, 215-223), later collections have brought in little to add there. The song has been specially studied by $\mathrm{H}$. Tampere, the customs context included (Tampere 1940).

In the Livonian tradition Easter was one of the most important days for making sacrifices. What could perhaps also be regarded as an offering were the leafy twigs used to decorate the fields where the young crop had just come up, buildings and, notably, boats. As leafy twigs are a widespread symbol of prospering vitality their use could also be considered as a case of contact magic. 
Beside that the Livonians are known to have offered up food and drink to Mother Sea. Of the numerous reports to that effect some say that Mother Sea was offered sacrifices by housewives who, as we know, usually did not go fishing. The usual offerings were spirits and whitebread, sometimes also sugar. According to most of the reports the offerings were brought to the seaside by young men and girls, who had come early Sunday morning to 'awaken the birds'. The syncretic character of the custom is reflected in a recording in which the receiver of the gift is alternately called Mother Sea and Mother Mary. As Easter coincides, more or less, with the beginning of the fishing season it is possible that originally sacrifices were offered up to Mother Sea when men first went out fishing in spring. Logically, the sacrifices would then be made by the men as the receivers of the expected return gift. (True, the sacrifices to mark the first going out to sea were different, consisting of objects directly connected with fishing, such as a piece of net, or rope, or of woollen yarn with its widespread magical connotations.) These were dropped into the sea to the accompaniment of certain wishing formulas analogous to those used with Easter offerings. This was done in the hope of getting fish as a return gift from Mother Sea and to avoid her possible wrath expressed in stormy weather, often resulting in loss of nets (Loorits 1926, 115-116).

As was mentioned above Easter offerings formed part of an early morning ritual called Birds' Awakening. The central component of the ritual was a song and one part of this song was dedicated to fishing magic. The primary motif of the song (according to H. Tampere) is an appeal to the birds asking them to wake up from their long winter sleep. The other main motif, also very resistant to time, is an incantation seeking good luck in fishing (Tampere 1970, 206-207). The motif consists of two verses containing the wish that fat sole should go to the fishermen of one's own village (or, more generally, one's own shores) and the lean sole should head for other villages (or shores). As is the case with many other spells and magic rites the underlying philosophy seems to be as follows: the amount of world wealth is constant, so its concentration in one place inevitably means its decrease somewhere else. So, if 'we' get something, 'they' would obviously have to go without. The same structure of oppositions pervades the whole song: good animals are wished to come to 'our' forest, wolves and bears to any other forest, nice boys to 'our' village, bad (ill-tempered, drinking) guys to any other village, beautiful girls to 'our' village, ugly girls to any other village. The lastmentioned wishes probably had a facetious character, in any case they have nothing to do with fishing. (photo *6)

H. Tampere has pointed out a structural similarity observable between the Livonian ritual song sung on Easter morning and an incantation recorded from Sõrve (Jämaja parish, Saaremaa), reading as follows: Tursad tulgu meie merde, muda mingu muude mutsa. ('Let the cod come to our seas, let mud go to the others' wood') (Tampere 1970, 207). But this incantation did not belong to Easter but to Shrove Tuesday. There is, however, a direct parallel hitherto overlooked by the researchers. It comes from Muhu and has been noted down, curiously enough, by O. Loorits. The relevant part of the record reads as follows:

... Vanad mehed laulsid:

"Suured kalad meite merde,

väiksed kalad teiste merde.

Siiad sibavad seenule,

aavid aavad akenuse."

Nad laulsid randas, lihatoma pühal. 
Old men would sing,

"Let big fish come to our sea, let small fish go to the others' sea.

Lavaret's wallowing up our walls, pikes are filling the windows."

On seashore it was sung, on Easter Sunday. - ERA II 33, 131(39).

As the reader will have noticed the first two verses bear a close resemblance to the fish motif of the Livonian song, in form as well as in contents. The following two verses, however, undoubtedly belong to the runic tradition. This is clear from the first sight of the abundant alliteration and assonance and also parallelism. The lavaret and pikes mentioned in the parallel verses sound familiar as they occur in many song types (Kalajõgi 'Fish River', Kaugele kalale 'Faraway Fishing Waters') and in some other paradigms connected with fish. The closest parallel text comes, as could be expected, from Muhu again. There is a wedding song called Kala tuleb koju 'Fish Coming to the House'. There we find such verses as:

\section{Muol o meri õuve alla,}

laevasadam alla sauna.

Vimmad mul ouve oeuvad,

siiad seenule sibavad,

avid aavad akenule.

I have the sea at my doorstep

and a harbour near the sauna,

bream is playing in my yard,

lavaret's wallowing up the walls,

pikes are filling the windows. - H II 54, 400 (62).

An ever so slightly different wording occurs in another text from Muhu (H II 6, 620/6 (3)). Although the above fishing spell was chanted at Easter like the Livonian Birds' Awakening song, it has never been part of a longer ritual. It must also be pointed out that this extremely interesting Muhu text has been noted down but once, which may mean that by the late 18th century when massive folklore collection began, the custom together with the song was already on its way out.

Another single report, this time from the Isle of Kihnu, tells us that nets had to be put down on Easter Sunday in order to guarantee a good haul for the summer. This fits among the fishing rites performed by the Estonians, Latvians and Livonians on Maundy Thursday and Good Friday, especially the making and smoking, but also the immersing of the nets. Such practices may be motivated in two ways: on the one hand one could perhaps expect a good catch like the one got by the disciples of Jesus; on the other hand, working on a central Christian holiday could perhaps be interpreted as an appeal to some anti-God forces. This looks all the more probable if we recall that the Livonian tradition contains some stories in which a good haul is devil-sent (Loorits 1927, 171172). 
To finish with the movable feasts of spring and early summer we can say that no direct connection either with fishing or the sea in general can be found in the Livonian customs for the Days of the Cross and Whitsuntide. Those days, espcially Ascension Day was connected with overall working bans, which may be interpreted as applying to fishing as well. The belief that storms are likely to happen on those days seems to emphasize that going out to sea on those days was not only inopportune, but possibly also dangerous. The Estonians, both on the northern and on the western coasts, have also considered storms as being characteristic of the Days of the Cross (Hiiemäe 1984, 189). The Latvians associate the Days of the Cross with general working bans as well, no special report connected with fishing has been registered (Smits II, 950-956). The single report of weelmaking at church time on Whitsunday is an obvious transference from customs belonging to some other dates (Hiiemäe 1984, 224).

Let us now turn to fixed feasts. Although O. Loorits has argued that vernal St. Nicholas' Day (May 9) is not reflected in the Livonian folk calendar, it is not quite true. The Livonians believed that this was the day for storks to arrive. This natural observation can be associated with fishing and the sea via a rather vaguely formulated text by Saarimaa. Notably, the Livonians are said to have believed that if a stork descended to the ground (in Finnish putosi maahan) on that day it meant that many men would be drowned that year. Motivation for this apprehension could perhaps be found in the association migratory birds were thought to have with the realm of the dead. That association was believed in by the Livonians alongside with the birds' hibernation, underlying the custom of having an early breakfast "to cheat the birds" before going out in the morning (Loorits 1949, 355-359). The Estonian word toonekurg 'stork' contains a direct reference to toonela 'the realm of the dead', while the Livonian word pivalind - püvalind (lit. 'holy bird') has an obvious sacred connotation too. It is not impossible that what the deficient text really meant was that it was important where the stork was first sighted in spring: if it was some higher place like in a tree or on a roof, it was considered a good omen, whereas his position low on the ground meant ill. (photo*7)

Although St. John's Day (June 24) was an important folk holiday, no sea- or fishing-specific beliefs or customs are associated with it. This is no wonder as the fishermen's working calendar has no turning point anywhere around that date. Like the Latvians (and probably under their influence) the Livonians used the day for overall decoration. Similarly to Easter leafy twigs and flowers were used to decorate buildings, fields and also boats. The decoration of boats on St. John's Day could perhaps be regarded as a thanksgiving to Mother Sea for her goodwill shown so far, as by that time the fishing season had lasted for quite a while, but a wish for future success is also logical to assume. An express mention of this function is made in the report of old boats being burnt in St. John's bonfires, thus offering them up to Mother Sea and asking her to bless the fish expected to catch.

There are also some observations of the routes taken by fish. The Livonians said that after St. John's Day bream would enter the brackish waters near river-mouths, whereas cod would appear in the dark "thick" waters. O. Loorits thinks that on the one hand the Livonian customs practised on St. John's Day include several elements taken over from the more genuine Easter tradition, while some other elements could evidently be attributed to the influence of the Latvian celebrations of St. John's. As we know, the last mentioned traditions are particularly rich and variegated, but their connections with fishing and the sea are practically absent. The Latvian fishermen from Kurland are also known to have burnt an old boat in St. John's bonfire (Smits II, 705). Reports of burning boats or ship fragments have also been collected from several regions of Estonia (Hiiemäe 1985, 53-54, $62)$. 
St. James' Day (July 25) has been regarded, in a way, as a dividing-point between summer and autumn. This was the day when haymaking was finished and the new crop tasted by the Livonians as well as by the Latvians and Estonians. As far as fishing is concerned there is a single Livonian report of sprats being of the best quality during the week of St James' Day. in general, however, the Livonians would prefer sprats caught in October and, accordingly, the sprat-fishing season did not even start before Lady Day (September 8), although some sprats were also caught in summer (Leinbock 1928, 110). From Latvians no reports have been received of any associations made between St. James' Day and fishing. There are a couple of reports from Estonia, according to which St. James' Day was considered a dividing point in fishing, but their contents are totally different (Hiiemäe 1985, 254).

Towards the end of summer and the approach of autumn, storms and other risks connected with the sea become increasingly topical. The earliest of such dates is St. Lawrence's Day (August 10) which was mainly associated with fire hazard and the preventive magic. That was true about both the Livonians and their neighbours. At the same time it should be kept in mind that the Livonians regarded St. Lawrence's Day as ill-starred in general, as this was the day when Sodom and Gomorrah had been destroyed which meant that the elements had been given a destructive power. Even the earliest record of St. Lawrence's Day in Livonia (Sjögren - Wiedemann, 307) says that on St. Lawrence's Night "the sea has nine waves" and this is why nets should not be put down as they would become entangled. The motif of nine waves together with a ban on going out to sea keeps recurring in later reports. To confirm the truthfulness of the firmly rooted conviction a story was sometimes told about a fisherman who had acted against the ban and gone out to sea on St. Lawrence's Day. Even though the weather had been fine at first, later a storm had broken and the man had lost all his nets. The warning of inevitable storms breaking on St. Lawrence's Day seems to be rather specific to the Livonian folk calendar. Although there is an Estonian warning saying that if St. Lawrence's Day is stormy, it portends accidents at sea, the belief that storms are inevitable on a certain day is rather connected with St. Bartholomew's Day (August 24). Moreover, the pertinent reports all come from Virumaa thus hardly having any genetic relationship with the Livonian traditional beliefs. The Latvians have connected the day with obsevation of and portents connected with the first frosts (Smits II, 997).

The Livonians - like the Estonians and unlike the Latvians - have connected the hazard of storms with St. Bartholomew's Day as well. Here, too, appears the motif of nine waves familiar from the St. Lawrence's tradition. The reports are, however, fewer in number and the ban on going out to sea on St. Bartholomew's Night has been - since 19th century at least - gradually losing its importance as compared to the bans and warnings connected with St. Lawrence's Day. For some reason or other this motif that is secondary on international level has come to dominate in Livonia, probably amplified by the common fear of fire hazard.

As Michaelmas (September 29) was considered the real beginning of autumn, there is various appertaining material in the Livonian folk calendar. Among the numerous reports there is one saying that going to sea was prohibited on Michaelmas. But as no explanation has been added, it could be that the ban was due to Michaelmas being a half-holiday.

The six weeks' period from Michaelmas to St. Martin's Day was the Ghosts' Visiting Time. The meteorological observations of that period contain frequent mention of the air hanging close and oppressive. Alongside go statements to the effect that the sea is very stormy and many a sailor 
would lose his life. It was also believed that that first three weeks of the period the wind would blow from one direction and when "half the ghosts" were over it would change to another direction from which it would keep blowing until Martinmas. As to the Latvians they have made many observations connected with the weather of that period, but no mention of particular storms can be found in their material (Smits IV, 1965). The established Estonian way to characterize the Ghosts' Visiting Time is to point out its specially quiet and windless nature (Hiiemäe 1991, 253, 255). There are also a few reports of the weather deteriorating and rainstorms occurring during that period, but these come from inland (Hiiemäe 1991, 257) and thus are hardly related to the Livonians' conviction of the sea being stormy at that time.

It should be pointed out that although most of the Livonian (as well as of the neighbouring people's) folk calendar bears traces of Catholic influences, the observation of Ghosts' Visiting Time belongs to a much older layer of genuine folk religion. Curiously enough a Lutheran date - the Day of Annual Commemoration of the Reformation (October 31) - also falls into this period. So the storm hazard is underlined by a ban on going out to sea for the whole week prior to this date. The week is considered just not proper for fishing.

St. Martin's and St. Catherine's Days are mostly famous for their mumming traditions. The meteorological observations point out signs of the approaching winter, snowfall, the alternation of frosts and thaws. No special beliefs or customs directly connected with fishermen's work are reported to have been observed either on those two days or on any other important date of that period (St.Andrew's Day on November 30, St. Barabara's Day on December 6, St. Nicholas' Day on December 9). Nevertheless the period marks the end of the economic year for fishermen as well. The fishing season ended, depending on the weather conditions of the concrete year, either in November or December.

So, before and at the beginning of the fishing season the main emphasis was laid on such rituals as were aimed at getting a good catch of fish, whereas towards the end of the season storm warnings take over, to prevail until there comes a break in the fisherman's calendar. At the end of the year attention began to shift to the forthcoming season. Christmas time, New Year included, was marked for special attention being paid to various omens, but sometimes sacrificing with the aim of exerting a favourable influence on the next season's catch could also be practised.

The break in the fisherman's work is reflected in the instruction that on Christmas Eve boats had to be turned bottoms up for a winter's rest, although fishing had usually been over for quite a while by that time. Symbolic was also the spreading of the nets done on Shrove Tuesday to mark readiness for the approaching fishing season, although actual fishing would start considerably later. It seems that symbolic rites to mark the beginning or end of a period just tended to gravitate to the major festivals closest at hand. In Estonia the symbolic upturning of boats to mark the end of the fishing season was practised in Sõrve (Hiiemäe 1995, 10-11). For geographic reasons the Livonians' ties were stronger with the fishermen from Saaremaa than with those from other regions of Estonia, and stronger with the fishermen of Sõrve than with those from the rest of Saaremaa. So, part of the common features of the Livonian and Sõrve folk cultures may be the result of a joint development, but in some cases one should not undersestimate the possible Livonian influence on the customs and traditions observed in Saaremaa. 
The Livonians tried to divine the next season's catch from the skies of Christmas and New Year's Nights. There are numerous reports to that effect, but there is no unanimity in the interpretation of what is observed. Sometimes a clear and starry sky on Christmas or New Year's Night could be interpreted as an omen of abundant fish caught next season. In some places it was believed that the fish would come from those quarters in which more stars could be discerned on the horizon. At the same time there are reports according to which a good fishing season was predicted, on the contrary, by overcast skies. Ante-midnight clouds were said to bring a good catch of sprats and Baltic dwarf herring, whereas bigger fish could be expected to be caught, if clouds appeared after midnight. Attention was also to be paid to the trees: if these were covered with hoarfrost on New Year's Day, it was considered a good omen for fishermen. (photo*8)

The skies were watched on Christmas and New Year's Nights and the occurrence of hoarfrost on trees was looked out for also by the neighbouring peoples. Both the Estonians and the Latvians have interpreted those phenomena as augural. The two have some common omens concerning the next year's crops, which are absent from the available Livonian material. There is but one belief shared by all three neighbours (and many other peoples) according to which a starry sky on Christmas or New Year's Night meant good luck with young animals. Here the centering of the Livonians' interests on fishing is especially conspicuous as against the typically poorish background of the available Livonian calendar traditions the abundance of fishing omens stands out clearly indeed. Notably, here the Livonian tradition differs considerably from the Latvian one, being at the same time closer to the Estonian tradition. But in Estonia the tradition was much less known, not only relatively, but absolutely as well. Of hundreds of reports on auguring from the Christmas or New Year's Eve's skies only a few are in any way connected with fishing. And, again, those come from Saaremaa and Hiiumaa which areas had Livonian contacts. The difference lies in that the Estonian islanders did not mark the number of stars, instead, they looked out for a special glow called kalakoit 'fish dawn', which direction was then expected to bring a bigger haul of fish in the summer.

Hoarfrost covering the trees could also mean various things both for the Estonians and the Latvians, including a good harvest either in general or of some concrete crop. Fishing prospects are not known to have been predicted from hoarfrost by the Latvians, but the Estonian material contains quite a number of such reports. And although it is possible that some of these may reflect literary influences, the roots seem to lie in the original folk tradition all right, while the sites of the corresponding information concentrate in western Estonia and on the islands.

So we may safely conclude that like Easter, Christmas time and the New Year have a strong association with seafaring and fishing. A custom common to both of the most important feasts of the year was an offering of spirits to mother Sea, sometimes it was also repeated on New Year's Eve. On the one hand the offering could have been inspired by a wish to share one's bounty with all creatures, fairy folks included, on the other hand there must have been a strong hope to get a return gift from Mother Sea at the forthcoming fishing season.

Having now completed the round of the year, we would like to dwell a little on the beliefs and customs connected with such temporal units as days of the week and lunar phases. More relevance seems to have bee attributed to the second half of the week. Friday is widely known as the day of ill luck almost throughout Europe. This may suffice to explain the Livonian ban on netmaking on that day. Probably it was feared that a net woven on a Friday would not catch any fish, or something would happen to the net. Neither was Friday considered a good day to start the fishing season, unless one specially wanted to run the risk of spoiling the whole season, of course. 
New nets were first put out in the first half of the week. It should never be done, however, on a Thursday night, otherwise ill luck would never leave the nets. There are relatively many reports connected with Thursday night. True, usually it says "Friday night", but as O Loorits has shown it actually means the eve of the day mentioned, analogously to St. John's or Christmas Eve, and that the special role of Thursday night reflects some old Germanic influence (Loorits 1950, 132-133). In terms of our present subject it is important to note that although some handiwork (knitting, sewing and patching) was allowed on Thursday night, these did not include spinning and netmaking. And although any sanction of ill luck befalling the reckless fisherman was not mentioned, it looks rather logical to follow. The Livonians also disapproved of going out fishing on Saturday, let alone Sunday. And nets could not be put down before past midnight whem Monday had set in.

Lunar phases were watched carefully both in connection with netmaking and with going out to sea. The periods of no moon or new moon were usually considered unfavourable. It was believed that a net made in new moon would certainly rot. That report is corroborated by the recommendation that nets should be made in full moon. Full moon was also considered the best time to start a fishing season. A full moon was expected to bring full nets.

As weather is a most important factor in fishing it is only to be expected that there are many reports associating different phases, shape and some other external features of the Moon with weather. An interlunar Friday was considered to be stormy. This derives from the widespread opinion that Friday as an ill-fated day is unsuitable for beginning anything. Storms were also expected to happen when new moon was lying on its side, or when the Moon had spots, or when there was a brush-like or a fence-like halo. In the last-mentioned case a hole in the "fence" was thought to be pointing to the direction of the wind. A common belief was that a new moon would bring a change in weather.

To summarize the above discussion it can be said that although there is some discrepancy between the proportions of customs and beliefs connected with fishing and the sea as represented in the available material on the Livonian folk calendar, and the relative importance of those items in the everyday life of the inhabitants of the Kurland coast, there are enough reports to prove that $\mathrm{O}$. Loorits' statement referred to towards the beginning of the present article must be an exaggeration. The Livonian folk calendar is one of off-shore fishermen all right. This calendar divides the year into two parts: the fishing season lasting from spring to autumn and the winter season when people did not go out to sea, but were busy making nets. The main dividing-points between the seasons were two central Christian feasts - Easter and Christmas. Easter seems to have attracted a number of customs that must have once belonged to the first day of going out to sea. Towards summer more attention began to be paid to offerings made in the hope for better luck in fishing, the best days to catch this or that fish, and meteorological observations, mostly warnings of storms. In winter, however, various portents were watched for, nets were made observing various instructions and bans, and other preparations were made for the next season.

The material available on the Livonian fishermen's calendar is rather homogeneous. This is no wonder as the material comes from quite a limited area. The Estonian material, on the contrary, manifests several different local traditions. The most prominent of them characterizes the coast of the Livonian Bay and the islands and is most directly connected with the Livonian tradition. The other two clearly definable groups are located on the North-Estonian coast and near Lake Peipsi. The smaller inland waterbodies seem to have inspired much less material, including many noncereports, while in contents they tend to those connected with Lake Peipsi. The Finnish fishermen's 
calendar is also quite variegated, but unlike Estonia the material is dominated by inland material. This is due to the fact that a major part of the Finnish coast has for centuries been inhabited by a Swedish-speaking population.

In comparison with the Latvians the Livonian folk calendar pays much more attention to the sea and fishing. This is especially noticeable at Easter when the Latvians endeavour all kinds of future success - except in fishing, whereas fishing stands in the fore with the Livonians. Neither is there any particular similarity observable between the fishing rites practised by the Latvians and the Livonians on other important dates. Instead, the Livonian fishing traditions reveal more kinship with the corresponding beliefs and customs of the Estonians from the coast of the Livonian Bay. These common features can hardly be referred to a common origin as the Estonian tradition is so different locally. The similarities seem rather to be due to active contacts in the recent past. Neither need the indigenous Livonian rites be any too old. Being relatively isolated, the narrow strip of Kurland coast may well have been a hotbed for some recent innovations such as some new sanction for breaking a working ban, or the association of some old rites with a new date etc. What is really old is the worship of Mother Sea, even though it has partly got fused with that of Mother Mary.

Generally the calendar tradition of the Livonian fishermen seem to support the argument that a small ethnos need not be a passive receiver of influences from outside, instead they may be active creators or at least selectors and adapters of the surrounding cultural phenomena to their own needs.

Translated by Sirje Ainsaar

\section{References and abbreviations}

Alho, V. (= Wallin-Voionmaa, V.) 1891. Liivin kansa, sen entisyys ja nykyisyys. Jyväskylä. EV = Eesti vanasõnad. Ed. A. Krikmann, I. Sarv. Comp. A.Hussar, A. Krikmann, E. Normann, V. Pino, I. Sarv, R. Saukas. I. Tallinn, 1980; II. Tallinn, 1984; III. Tallinn,1985.

Hiiemäe, M. 1981. Eesti rahvakalender II. Tallinn.

Hiiemäe, M. 1984. Eesti rahvakalender III. Tallinn.

Hiiemäe, M. 1985. Eesti rahvakalender IV. Tallinn.

Hiiemäe, M. 1991. Eesti rahvakalender V. Tallinn.

Hiiemäe, M. 1995. Eesti rahvakalender VII. Tallinn.

Leinbock, F. (= Linnus, F.) 1928. Liivlaste kalastusest ja vähipüügist. Eesti rahva muuseumi

aastaraamat IV. Tartu, pp. 109-151

Loorits, O. 1927. Liivi rahva usund II. Tartu.

Loorits, O. 1936. Volkslieder der Liven. Õpetatud Eesti Seltsi Toimetused XXVIII. Tartu.

Loorits, O. 1949. Grundzüge des estnischen Volksglaubens I. Lund.

Loorits, O. 1950. Das livische Kalendarium. Arv. Tidskrift för nordisk folkminnesforskning

VI.Uppsala.

Loorits, O. 1958. Eine altrussische Tradition bei den Liven und Letten.Commentationes Balticae.

Vol. 4/5. Bonn.

Loorits, O. Liivi rahva usund IV. (MS at the Estonian Folklore Archives)

Mälk, et al. 1981. Liivi vanasõnad eesti, vadja ja läti vastetega I-II. Tallinn. 
Lätt, S. 1970. Eesti rahvakalender I. Tallinn.

Lätt, S. 1971. Tõnisepäeva traditsioonidest. Paar sammukest eesti kirjanduse uurimise teed VII. Tartu, pp. 123-134

Salve, K. 1984. Sanditamine liivlastel. Paar sammukest eesti kirjanduse uurimise teed X. Tallinn, pp. 83-119

Salve, K. 1987. Talvine nigulapäev liivi rahvatraditsioonis. Rahvaluulest. Eesti NSV Teaduste Akadeemia Emakeele Seltsi toimetised. Tallinn, pp. 201-215

Sjögren, J A., Wiedemann, F.J. 1861. Livische Grammatik nebst Sprachproben. Im Auftrage der Kaiserlichen Akademie der Wissenschaften bearbeitet und mit einer historisch-ethnographischen Einleitung versehen von F. J. Wiedemann. St.-Petersburg.

Smits, P. 1940-1941. Latviesu tautas ticejumi. I - IV. Riga.

Tampere, H. 1970. "Lindude äratamine" liivlaste rahvatraditsioonis. Läänemeresoome rahvakultuurist. Tallinn, pp. 193-225 